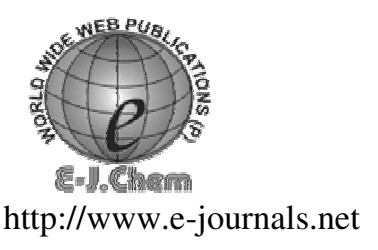

\title{
Effect of Chemical and Physical Properties of River Water in Shatt Al-Hilla on Phytoplankton Communities
}

\author{
FIKRAT M. HASSAN ${ }^{*}$, NUHA F. KATHIM ${ }^{\S}$ and FALAH H. HUSSEIN ${ }^{\#}$ \\ ${ }^{*}$ College of Science for Women, University of Baghdad, Baghdad, IRAQ \\ ${ }^{\#}$ College of Science, University of Babylon, Hilla, IRAQ \\ abohasan_hilla@yahoo.com
}

Received 4 July 2007; Accepted 28 September 2007

\begin{abstract}
This paper aims to study the chemical and physical properties in the ecological system of Shatt Al-Hilla in Babylon Governorate in Iraq and its effect on phytoplankton population. In this context, several limnological parameters were evaluated during the period from December 2003 through November 2004 from four sampling stations sited along Shatt Al-Hilla. The physical parameters included: temperature, turbidity and electrical conductivity. The chemical parameters included: $\mathrm{pH}$, alkalinity dissolved oxygen, total hardness and the concentrations of nitrite, nitrate, phosphate and sulphate. A total of 154 species were recorded. Ninety-seven species of the total belong to Bacillariophyceae, 37 species belong to Chlorophyceae, 13 species to Cyanophyceae, 5 species to Chrysophyceae, and 2 species to Euglenophyceae. Bimodal variation of phytoplankton was observed. Five genus of phytoplankton were the highest number of species ( Nitzschia, Navicula, Gomphonema, Cymbella and Scendesmus). Some species was occurred continuously during study period such as, Cyclotella ocellata, Cyclotella meneghiniana, Aulacoseria distans, and Gomphonema abbreviatum. The phytoplankton communities at all sampling sites showed a clear seasonal variation in phytoplankton cell number. However, no significant correlation between total cell number of phytoplankton and nutrient concentration was observed. The study was revealed the city sewage discharge, agriculture and urban run-off were affecting the water quality of Shatt Al-Hilla.
\end{abstract}

Keywords: Chemical and physical parameters, River water, Shatt Al-Hilla Ecological system, Phytoplankton. 


\section{Introduction}

The studies on lotic phytoplankton are in many ways less advanced than studies on the phytoplankton of standing water ${ }^{1 .}$ In Iraq, the running water have received less attention than those of lakes and reservoirs, most of Limnological studies has been done on the upper region of Euphrates and some localities at southern part. These regions were studied by several authors ${ }^{2-6}$.

The Euphrates River is ramified into two rivers namely Hindia and Shatt Al-Hilla (named Hilla river in some references) at its middle region ${ }^{7}$. Shatt Al- Hilla is passing through numerous towns and villages, with the exception of effluents from domestics, agriculture and industries wastewater. Its total length is a bout $103 \mathrm{~km}$ with a discharching $250 \mathrm{~m}^{3} / \mathrm{sec}$. The river is gradient $7 \mathrm{~cm}$ to each $1 \mathrm{~km}$ overall fall.

Shatt Al-Hilla has received less attention than those other region of Euphrates River. Limnological works on the water quality (physicochemical) and phytoplankton of Shatt AlHilla started at Babylon Governorate (Iraq) in 1995, when Hassan and Al-Saadi ${ }^{8}$ carried out a survey on phytoplankton distribution in the river, followed by Hassan ${ }^{7}$ investigation on physical and chemical characteristics of the river. In our previous study ${ }^{9}$ different physical and chemical parameters were used to evaluate the quality of river water and most of the observed results revealed a deviation from the national standards. Moreover, the evaluation of soluble essential and non-essential trace metals in Shatt Al-Hilla were studied recently ${ }^{10-11}$. The elevation of the concentration of some of these metals on the WHO guideline was explained due to contamination of Shatt Al- Hilla by human and/or industrial activities.

Many previous studies showed the effect of lotic characteristics on composition of phytoplankton and its changes response to the environmental fluctuation. Holmes and Whitten ${ }^{12}$ studied the phytoplankton of fast-flowing rivers in north-east England. They found that the diatoms formed the majority of cells samples. Jin et al. ${ }^{13}$ showed the relationship between phytoplankton and the concentration of nutrients in Sonaktong River in Korea, the study was showed that phosphorus and nitrogen were the limiting factors on the living biomass of the phytoplankton.

The objectives of this study were firstly to estimate selected data for definition of certain physical and chemical characteristics of Shatt Al-Hilla river and secondly, to make a qualitative and quantitative study of phytoplankton. The study also conducted to determine whether natural and industrial processes affect the magnitude and change in magnitude of a number of physical, chemical and phytoplankton variables.

\section{Experimental}

\section{Materials and methods}

The present investigation area (55 km length) was chosen along Shall Al-Hilla and lies on latitudes between $32^{\circ}$ to $33^{\circ}$ and longitudes $44^{\circ}$ to $45^{\circ}$ with water depth of 4-4.9 meters, it passes through Hilla city in Babylon province. Four sites were chosen; two sites (1 and 4) are located on the north and southern part of Hilla city and the other two (2 and 3) near by the city (Fig.1).

Each sampling sites were visited monthly for the period from December 2003 through November 2004. Air and water temperature, $\mathrm{pH}$ and electric conductivity were measured in situ using a thermometer (accurate to nearest $0.1^{\circ} \mathrm{C}$ ), $\mathrm{pH}$ - meter (model HANNA), and conductivity meter( model Bischof L17) respectively. Salinity values were calculated from electric conductivity values following Mackereth $e t a l^{14}$. Dissolved oxygen, total alkalinity, total hardness, calcium, magnesium and sulphate were estimated following APHA ${ }^{15}$. Nitrite, nitrate and phosphate were estimated following Parsons et al ${ }^{16}$. 
According to a previous study ${ }^{17}$ phytoplankton population are measured using a sedimentation technique, the micro transect methods was used for counting diatoms (Bacillariophyceae) and haemocytometer methods for other groups. Phytoplankton net samples were used for identification following previous studies ${ }^{16-24}$. Analysis of variance (ANOVA) was used to show the level of significant difference.

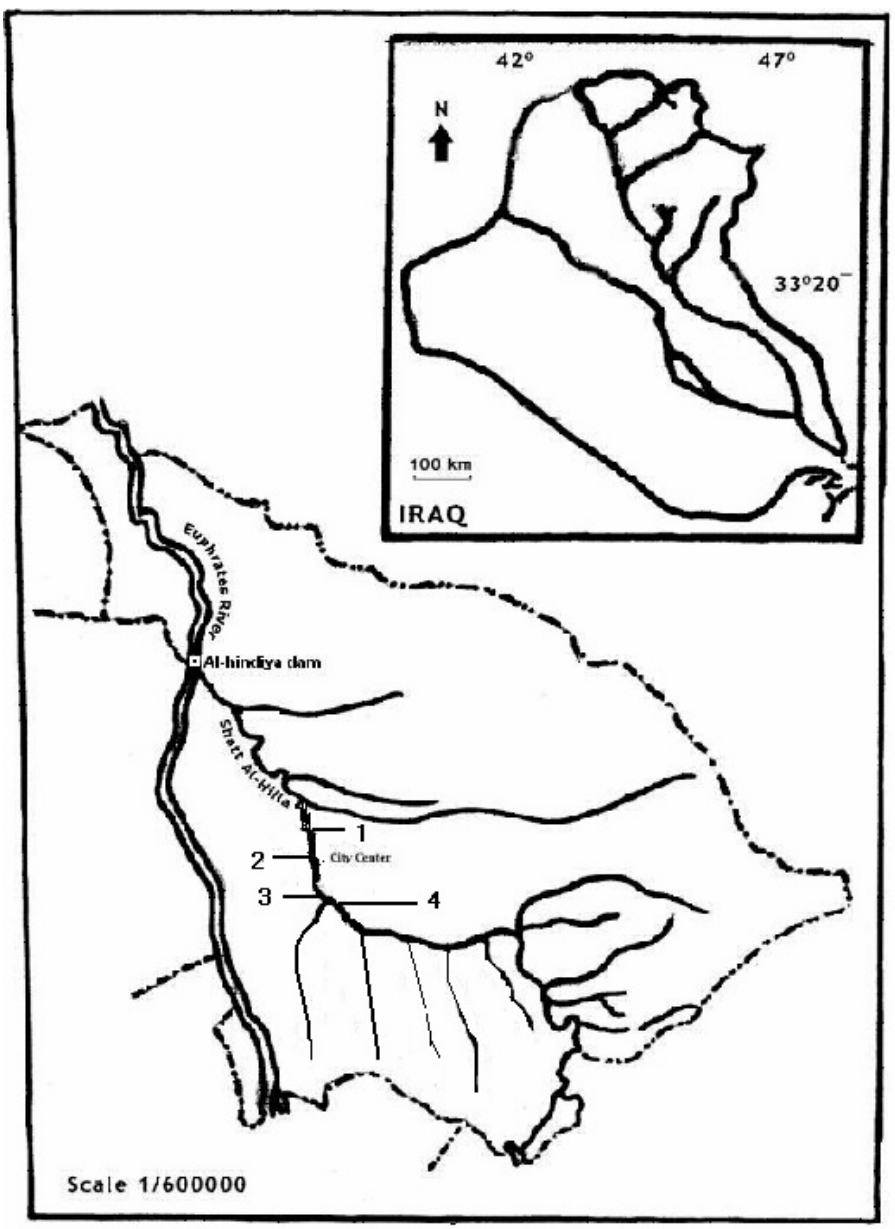

Figure. 1. Sampling positions

\section{Results and Discussion}

The temperature of air and water values were ranged between $10.6-43{ }^{\circ} \mathrm{C}$ and $10.3-32{ }^{\circ} \mathrm{C}$ respectively in January and July 2004 for air temperature, and in April and July 2004 for water temperature (Table 1), which are these values followed almost identical seasonal cycles. No significant variation found between temperature values and the sites during the study period.

The electric conductivity values were ranged from $400 \mu \mathrm{S} . \mathrm{cm}^{-1}$ recorded in June 2004 at site 1 , to $2000 \mu{\mathrm{S} . \mathrm{cm}^{-1}}$ at site 1 and 3 in December 2003. A similar pattern the salinity was fluctuated at all sites from $0.2 \%$ at site 3 in June 2004 to $1.2 \%$ at site 3 in April 2004 (Table 1). There was negative significant relation between electric conductivity values and water temperature $(r=0.57, \mathrm{P}<0.01)$ and no significant difference between the sites. 
$\mathrm{pH}$ values were ranged from 7.1 to 8.2 at sites 3 and 4 in August and January 2004 respectively. High values of dissolved oxygen were recorded in winter and spring seasons, with lowest values in summer and autumn seasons. These values were ranged $1.2-11.5$ mg. $\mathrm{L}^{-1}$ at site 3 in August 2004, and at site 3 in May 2004 respectively (Table 1).

The values of total alkalinity were ranged $51-264 \mathrm{mg} \mathrm{CaCO}_{3} \cdot \mathrm{L}^{-1}$ at sites 1 and 3 during October and January 2004 respectively (Table 1). The statistical analysis showed a significant difference between site 3 and other sites.

The results of total hardness were showed lowest values during September and October 2004 (340 mg. $\left.\mathrm{L}^{-1}\right)$ at site 4, while highest values were recorded during January 2004 at site 3 , there was no significant difference recorded among study sites. Calcium concentration was ranged $48.09-224.4 \mathrm{mg} \mathrm{CaCO} 3 . \mathrm{L}^{-1}$ at site 1 in October 2004 and at site 3 in October 2004 respectively (Table 1). A significant difference was recorded between site 3 and other study sites, and positive significant relation between calcium concentration and water temperature $(r=0.46, P<0.01)$. Magnesium values were generally less than recorded for the calcium, with range $2.06-180.8 \mathrm{mg} . \mathrm{L}^{-1}$ at site 4 and 3 during July and January 2004 respectively. No significant difference between study sites was recorded, while a significant relation was recorded with total hardness $(\mathrm{r}=0.705, \mathrm{P}<0.01)$.

The concentration of nitrite was ranged ND- $81.5 \mu \mathrm{g}$ atom $\mathrm{N}_{2}-\mathrm{NO}_{2}^{-} \cdot \mathrm{L}^{-1}$ at site 1 and 2 in December and November 2004 and site 3 in December 2004 respectively. A significant difference was recorded between site 3 and other sites. Nitrate concentration was ranged between 20.7 to $486.2 \mu \mathrm{g}$ atom $\mathrm{N}_{2}-\mathrm{NO}_{3}{ }^{-} \mathrm{L}^{-1}$ at sites 4 and 1 during Augustus and May 2004 respectively. The level of phosphate in most sites was ND during different months. High values were recorded at site 3 in November 2004. The sulphate values were ranged 46.6$1660 \mathrm{mg} . \mathrm{L}^{-1}$ at site 4 in June 2004 and at site 3 in April 2004 respectively (Table 1), a significant difference was recorded between site 3 and other study sites, and also there was a significant correlation with electric conductivity, salinity and total alkalinity $(\mathrm{r}=0.553$, $\mathrm{P}<0.01 ; \mathrm{r}=0.561, \mathrm{P}<0.01 ; \mathrm{r}=0.451, \mathrm{P}<0.01$ respectively).

Phytoplanktons were collected from the study sites of Shatt Al-Hilla during the period of study. A total of 154 species were recorded of which 97 species belong to Bacillariophyceae (7 species belong to centrals and 90 to Pennales), 37 species belong to Chlorophyceae, 13 species to Cyanophyceae, 5 species to chrysophyceae, and 2 species to Euglenophyceae. The site 1 was recorded the highest number of species (95 species), then the site 2 (91 species), and site 4 (80 species), while the lowest number of species was recorded at site 3 ( 79 species).

Five genus of phytoplankton were the highest number of species (Nitzschia, Navicula, Gomphonema, Cymbella and Scendesmus). Some species was occurred continuously during study period such as, Cyclotella ocellata, Cyclotella meneghiniana, Aulacoseria distans, and Gomphonema abbreviatum.

An interesting feature was the relatively high number of Chlamydomonas spp and Chlorella spp recorded in April, May and November 2004 at all study site. Quantities study was showed clear seasonal variation in phytoplankton cell number. The results for total cell number of phytoplankton were showed different between the study sites. In site 1 , the total cell number was ranged from 109- $5459 \times 10^{3}$ cell L ${ }^{-1}$ during February and April 2004 respectively. While in other site were ranged as 128-3863, 194- 2864, 90.3-3585 x10 $0^{3}$ cells $\mathrm{L}^{-1}$ at sites 2, 3, 4 during December 2003- April 2004, March- May 2004, and December 2003- May 2004 respectively. The present study was not recorded any significant correlation between total cell number of phytoplankton and nutrient concentration 
Table 1. Mean \pm SD (range) of some physical and chemical parameters and the total cell number of phytoplankton in Shatt Al-Hilla

\begin{tabular}{|c|c|c|c|c|}
\hline Characteristics & Site 1 & Site 2 & Site 3 & Site 4 \\
\hline \multirow[t]{2}{*}{ Temperature ${ }^{\circ} \mathrm{C}$ air } & $24.8 \pm 9.6$ & $28.5 \pm 9.7$ & $27.7 \pm 8.3$ & $28.8 \pm 10.2$ \\
\hline & $(10.6$ & $(10.6-43.0)$ & $(10.6-39.0)$ & (10.7-43.0) \\
\hline \multirow[t]{2}{*}{ Water } & $22.1 \pm 7.9$ & $23.0 \pm 7.5$ & $23.5 \pm 6.9$ & $22.7 \pm 7.6$ \\
\hline & $(10.3-31.0)$ & $(10.5-32.0)$ & $(10.9-39.0)$ & $(10.5-32.0)$ \\
\hline Electric conductivity & $847.5 \pm 413.7$ & $787.5 \pm 161.6$ & $1030.8 \pm 468.6$ & $791.6 \pm 189.2$ \\
\hline iS.cm-1 & $(450-2000)$ & $(600-1000)$ & $(600-2000)$ & $(500-1000)$ \\
\hline \multirow[t]{2}{*}{ Salinity $\%$} & $0.4 \pm 0.2$ & $0.4 \pm 0.1$ & $0.6 \pm 0.3$ & $0.4 \pm 0.1$ \\
\hline & $(0.2-1.2)$ & $(0.3-0.6)$ & $(0.3-1.2)$ & $(0.3-0.6)$ \\
\hline \multirow[t]{2}{*}{$\mathrm{pH}$} & $7.6 \pm 0.2$ & $7.6 \pm 0.2$ & $7.5 \pm 0.2$ & $7.7 \pm 0.2$ \\
\hline & $(7.4-8.0)$ & $(7.4-8.1)$ & $(7.1-7.8)$ & $(7.4-8.4)$ \\
\hline Dissol & $5.7 \pm 2.2$ & $4.8 \pm 2.9$ & $4.4 \pm 3.5$ & $5.9 \pm 2.5$ \\
\hline mg. & $(1.9-10.5)$ & $(1.5-10.5)$ & $(0.5-11.5)$ & $(2.1-11)$ \\
\hline Total a & $111.6 \pm 27.0$ & $116.3 \pm 18.1$ & $146.9 \pm 64.5$ & $104.2 \pm 23.7$ \\
\hline $\mathrm{mg} \mathrm{CaC}$ & $(51-148)$ & (91.0-144.0) & $(30.0-264.0)$ & ( 64.0-148.0) \\
\hline Total ha & $553 \pm 151$ & $538 \pm 152$ & $623 \pm 174$ & $500 \pm 134.4$ \\
\hline $\mathrm{mg} \mathrm{Ca}$ & $(400-880)$ & $(356-820)$ & $(400-1060)$ & $(340-840)$ \\
\hline \multirow[t]{2}{*}{ Calcium mg. $\mathrm{L}^{-1}$} & 111.838 .7 & $109.5 \pm 39.6$ & $152.6 \pm 49.1$ & $96.4 \pm 36.8$ \\
\hline & ( 48.0-1 & ( 52.1-176.3) & (92.1-224.4) & $(56.1-168.3)$ \\
\hline Magnesium & $54.3 \pm 45.0$ & $58.7 \pm 28.6$ & $61.0 \pm 42.7$ & $57.2 \pm 27.7$ \\
\hline $\mathrm{mg} . \mathrm{L}^{-1}$ & $17.2-169.1)$ & $(22.3-118.0)$ & $(22.6-180.8)$ & ( $2.0-103.7)$ \\
\hline Nitrite $\mu \mathrm{gm}$ at & $4.5 \pm 4.0$ & $4.1 \pm 4.9$ & $19.4 \pm 24.9$ & $3.3 \pm 2.6$ \\
\hline $\mathrm{N}-\mathrm{NO}_{2} \cdot \mathrm{L}^{-1}$ & (1) 117 & ( $0.0-15.0$ & $(0.4-81.5)$ & $(0.1-9.2)$ \\
\hline Nitra & $173.8 \pm 132.5$ & $140.6 \pm 91.5$ & $166.7 \pm 111.3$ & $123.9 \pm 81.4$ \\
\hline $\mathrm{N}-\mathrm{NC}$ & ( $38.4-48$ & $(36.2-306.4)$ & $(28.3-333.0)$ & $(20.7-291.2)$ \\
\hline Phosphate $\mu \mathrm{gm}$ & $13.1 \pm 22 . .6$ & $7.1 \pm 9.9$ & $16.4 \pm 20.8$ & $2.9 \pm 9.5$ \\
\hline atP-PO ${ }_{4} \cdot \mathrm{L}^{-1}$ & & $(0.1-025.0)$ & $(0.0-66.5)$ & $(0.0-33.2)$ \\
\hline Sulphate $\mu \mathrm{gm}$ at & $389.1 \pm 118.7$ & $335.9 \pm 133.9$ & $559.1 \pm 436.6$ & $313.8 \pm 121.8$ \\
\hline $\mathrm{S}-\mathrm{SO}_{4} \cdot \mathrm{L}^{-1}$ & $(214.2-580)$ & ( 204.0-622.0) & (197.1-1660) & ( 146.6- 580.0) \\
\hline $\begin{array}{l}\text { Total No. } \\
\text { phytoplankton x } \\
10^{3} \text { cell. } \mathrm{L}^{-1}\end{array}$ & $\begin{array}{l}1463.7 \pm 1817.9 \\
(109.0-5459.5)\end{array}$ & $\begin{array}{c}1295.3 \pm 1305.1 \\
(128.0-3863.7)\end{array}$ & $\begin{array}{l}1295.3 \pm 1305.1 \\
(128.0-3863.7)\end{array}$ & $\begin{array}{l}1295.3 \pm 1305.1 \\
(128.0-3863.7)\end{array}$ \\
\hline
\end{tabular}

An examination of selected variables over a course of time provides some tentative limits by which to judge past, present and future events in the ecosystems.

Water temperature was followed similar seasonal cycle of air temperature, the statistical analysis was showed that there was a significant correlation between air and water temperature, also there was no significant difference between sites. According to Reid ${ }^{25}$ classification (0.5- 5\%o as oligohaline) Shatt Al-Hilla was considered as oligohaline (0.1-1.2 \%o), the run off the agriculture wastes may be responsible for the highest values of salinity in the river during study period $^{26}$. A significant negative correlation was recorded between electric conductivity and water temperature $(\mathrm{r}=-0.570, \mathrm{P}<0.01)$, while there was no significant difference between sites. These results were agreed with other studies on the same river $^{7-8}$.

Little seasonal fluctuation of $\mathrm{pH}$ values were showed in this study. The recorded range of $\mathrm{pH}$ values in present study were general in accordance with the $\mathrm{pH}$ values of fresh 
waters ${ }^{27}$ and agree with Iraqi published data ${ }^{6-7,28-29}$. The statistical analysis was showed no significant correlation between $\mathrm{pH}$ values and total cell number of phytoplankton, for that may be the run off from farmland and domestic have more effect on $\mathrm{pH}$ values. These results were agreed with other studies ${ }^{30-31}$.

The clean river is characteristics by high concentration of dissolved oxygen; in present study the most values of dissolved oxygen is $<7 \mathrm{mg}$. $\mathrm{L}^{-1}$, and the most lowest values recorded at site 3, which is represented the site of discharge point of most civilian activities of Hilla city. The results were showed the range of total alkalinity within the natural inland water ${ }^{32}$, these values were may be related to concentration of dissolved oxygen, $\mathrm{pH}$ values and calcium concentration $^{33}$. The statistical analysis was showed a significant difference between site 3 and other study sites. A positive correlation between total alkalinity and water temperature $(\mathrm{r}=0.370, \mathrm{P}<0.01)$, electric conductivity $(\mathrm{r}=0.460, \mathrm{P}<0.01)$, and salinity $(\mathrm{r}=0.472, \mathrm{P}<0.01)$.

According to Lind $^{25}$ classification based on total hardness, Shatt Al-Hilla water is described as very hard, this results was agree with other studies on the same river $^{7,31}$ and also with the study on Washita River at Oklahoma ${ }^{34}$. All the concentration of calcium were higher than magnesium concentration among most of the study period at all sites, that probably due to high abilities of calcium ion to react with dioxide carbon more than for magnesium ${ }^{35-36}$.

Nitrite and nitrate concentrations were depended on the serial microbial transformation which also depends on dissolved oxygen value ${ }^{37}$. Throughout the study period the nitrate was not recorded at level that would be limiting phytoplankton growth in Shatt Al-Hilla. The high values of nitrate was recorded during winter and spring seasons, this is may be due to high values of oxygen, also presumably, because much of their input resulted from land drainage and urban run off ${ }^{17,38}$, and the decrease of concentration during the end of summer and autumn was maybe due to uptake by phytoplankton ${ }^{35}$. No significant difference among sites was found for nitrate, while a significant correlation was appeared between site 3 and other sites for nitrite.

The phosphate concentration was showed relatively low (most time undetectable during this study), and that was in agreement with other studies on the same $\operatorname{river}^{7-8}$. The higher recorded concentration at site 3 during winter, spring and autumn was maybe due to the input resulted from city sewage discharge, land drainage and urban run-off. The statistic analysis was showed no significant difference among all study sites, but there was a negative significant correlation with $\mathrm{pH}$ and dissolved oxygen $(\mathrm{r}=-0.286, \mathrm{P}<0.01$, and $\mathrm{r}=-0.341$, $\mathrm{P}<0.01$ respectively), while there was a little positive significant correlation with total alkalinity and nitrite $(\mathrm{r}=0.362, \mathrm{P}<0.01$, and $\mathrm{r}=0.362, \mathrm{P}<0.01$ respectively).

Sulphate is common form of sulfur in freshwater ${ }^{39}$.The present study showed a high level of sulphate in Shatt Al-Hilla. Similar results were recorded at other Iraqi aquatic systems ${ }^{40-42}$.

Bacillariophyceae have been reported by many authors to be the dominants in the phytoplankton composition as it's in this present study ${ }^{8,22,43-44}$. Chlorophyceae was the second groups after Bacillariophyceae in the number of identified species, these results also agree with study on Grand River in Oklahoma ${ }^{45}$ and also in agreement with other studies in Iraq $^{36,46}$. Cyanophyceae was represented by 13 species, most of them were recorded in summer season (especially in June, Augusts and September, when temperature was above $23 \mathrm{C}^{\circ}$, these results were agree with other studies ${ }^{47-48}$. Most of identified phytoplankton in Shatt Al-Hilla was derived from the benthos.

The maximum density of phytoplankton was occurred during late spring (April 2004), and then decreased a gradually in summer season. There was a further increase during autumn season. This was also observed in temperate area ${ }^{1,49}$. And this maximum was 
recorded at site 1; this was corresponded to available nutrients and other physical and chemical factors which promote the growth of phytoplankton. While the minimum total number of phytoplankton was recorded at site 3, this was due to the effluent of domestic discharge wastewater (there was not treated plant in the city). In general, the statistic analysis was showed no significant correlation between total cell number of phytoplankton and nutrients concentration

\section{Conclusions}

The city sewage discharge, agriculture and urban run-off were affecting the water quality of Shatt Al-Hilla, and that was appearing clearly at sites 2 and 3, where the wastewater is discharging to the river without any treatments. The most Bacillariophyceae was pinnate form which was dominant during the study period. That was agreeing with the fast flowing characteristic of Shatt Al-Hilla.

\section{References}

1. Whitten A B, Algae In: Whitten, A B Ed. River Ecology. Blackwell, Oxford, 1975, 725, pp. 81-105.

2 Shaban A AG, An Ecological study on phytoplankton in Dokan Lake. M.Sc. Thesis, Univ. of Sulaimaniyah (Iraq). 1980.

3. Al-N' mma B A B, A study on the limnology of Tigris and Euphrates. M. Sc. Thesis, Univ. of Salahaddin (Iraq), 1982.

4. Nurul-Islam A K M and Hameed H A, Check list of algae with a note on limnological and oceanographic studies in Iraq (1947-1982). Asiatic Society of Bangladesh, 1985, pp 63.

5. Kassim T I, Al-Saadi H A and Al-Lami A A, Sci. J. of IAECI, 1999, 1, 99.

6. Hassan F M, J. of Um. Salama for science, 2004 1(1), 119.

7. Hassan F M, J. Sci, Al-Mustansiriya., 1997, 8(1), 22.

8 Hassan F M and Al Saadi H A, J. Coll. Edue. For women, Univ. Baghdad, 1995, 6(2), 55.

9. Hussein F H Battol M, Al- Adily, Sawsan S, Taj Al-Deen and Mayson M AlTaee,Yemeni J. Sci.,2005, 6(2), 31.

10 Hussein F H, Al-Tee M M, Alkhateeb A N and Abid F M, Asian J. Chem., 2007, 19(1), 724.

11. Al-Tee M M, Alkhateeb A N, Hussein F H and Abid F M, Asian J. Chem., 2007, 19(1), 741.

12. Holmes N T H and Whitton B A, Hydrobiologia, 1981, 80,111.

13. Jin A L, Choi A R and Kyechung I K, The Korean Journal of physiology, 1995, 10(1), 37.

14. Mackereth $\mathrm{F} \mathrm{J} \mathrm{H}$, Heron $\mathrm{J}$ and Talling $\mathrm{J}$ T, Sci. publ. fresh water, Biol. Ass. (England), 1978, 36, 1.

15. APHA, Standard Methods for the Examination of Water and Wastewater. $20^{\text {th }}$. Ed. American Public Health Association, Washington ,DC, 1985.

16. Parsons T R, Mait Y and Laulli C M, A manual of chemical and biological methods for seawater analysis pergamone press Oxford, 1984.

17. Hadi R A M, Algal studies of the River USK. Ph D. Thesis, Uni. Col. Cardiff, 1984.

18. Prescott G W, Algea of the western Great Lakes Area. William, C., Brow, Co. Publishers, Dubuque, Lowa., 1973, pp. 977.

19. Foged N, Fresh water Diatoms in sprilanka (Ceylon). Bibliotheca phycologia. Herausgeben Von J. Cramer Bond 1976, 23. 
20. Foged N, Freshwater Diatomsin in Ireland. Bibliotheca ghycologia.Herausgegeben Von J. Cramer Band , 1977, 34.

21. Hustedt F, "The pinnate distoms 2-An English translation of Husted F. Dickiselal genteilz", with supplement by Jensen Iv. Kocwingstein, Gylcoeltz, Sci., Books 1985.

22. Hadi R A M, Al-Saboonchi A A and Haroon A.K.Y, Nova Hedwigia., 1984, 39, 513.

23 Germain H, Flora des Diatomèes (Diatomphycèeae) eaux douces et saumàtres du Massif Armoricain et des contrèes voisines d' Europe Occidentale. Boubèe, Paris, 1981, p 444.

24. Hustedt F, Bacillariophyta A, Pascheri Diesusswasser- Flora mitteleurope. Heft, 1930, 10, 1.

25. Reid G K, Ecology of inland waters and estuaries. D. Van Nostrand. Co., New York, 1961.

26. Pota Pova M and Charles D F, Fresh Water Biology, 2003, 48, 1311.

27. Calderoni A and Turtari G, J Limnology, 2001, 60(1), 89.

28. Maulood B K, Hinton G C F, Kamees H S, Saleh F A K, Shaban A A and Al-M.H, Tropical Ecology, 1979, 20(1), 27.

29. Al-Saadi H A, Kassim T I., Al-Lami A A and Salman S K, Limnologica, 2000, 30, 83.

30. Jalut Q H, Evaluation of water quality parameters of water supply stations in Babylon Governorate, Univ. of Babylon, Engineering Science 1998, 5(3), 500.

31. Taj Al-Deen S S H, The study of water hardness in Al-Hilla river and how to treat it for industrial uses in the general state of textile industry. M. Sc. Thesis, Uni. of Babylon ( Iraq), 2001.

32. Antoine S E and Al-Saadi H A, International Rev. Hydrobiologia , 1982, 67(3), 405.

33. Brown A L, Ecology of Fresh Water. Heinemann Edu .Books Ltd., 1980.

34. Madden M P and Morris W K, Proc. Okla. Acad. Sci., 1978, 58, 88.

35. Munawar M, The biotope hydrobiologia , 1970, 35(1), 127.

36. Al-Saadi H A and Antoine S E, Hydrobiologia, 1983, 99, 189.

37. Lampert $\mathrm{W}$ and Sommer U, Limnology: The ecology of Lakes and streams, translated by Haney, J F, Blackwell, Oxford , 1997.

38. Goldman C R and Horne A J, Limnology-Megraw Hillint. B. Co., U.S.A., 1983.

39. Wetzel R G, Limnology. $3^{\text {rd }}$ Ed. Elsevier Science (USA), 2001.

40. Rzoska J Ed., Euphrates and Tigris Mesopotamian Ecology and Desting. J. W. Junk, 1980.

41. Al-Lami A A, Al-Saadi H A, Kassim T I and Farhan R K, J. Coll.Edu. for Women, 1999, 10, 2 .

42. Salman J M, Environmental study of some possible pollutants on Euphrates River between Al- Hindia dam and Al-Kufa-Iraq. Ph.D. Thesis, Uni. of Babylon (Iraq), 2006.

43. Polat S and Sarihan E, Turk J. Bot. 2000, 24, 1.

44. Polat S and Isik O, Turk J. Bot. 2002, 26, 77.

45. Pfiester L A, Lynch R and Wright T L, Proc. Okla. Acad. Sci, 1980, 60, 63.

46. Al-Handal A Y, Al-Assa S A and Al-Mukhtar M A, J. Mar. Sci. Cent. Univ. of Basrah, 1989, 4(1), 67.

47. Gross J L. and Pfiester L A,. Proc. Okla. Aca. Sci., 1988, 68, 39.

48. Cronberg G, Annadotter H and Lawton L A, Hydrobiol., 1999, 404, 123.

49. Al-Saadi H A and Antoine S E, Verh. Internet Verein-limnol. Bd, 1981, 21, 880. 


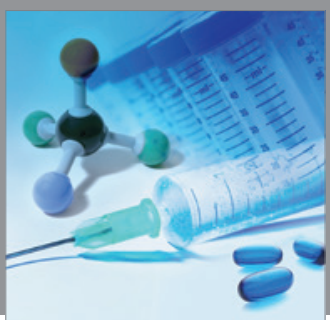

International Journal of

Medicinal Chemistry

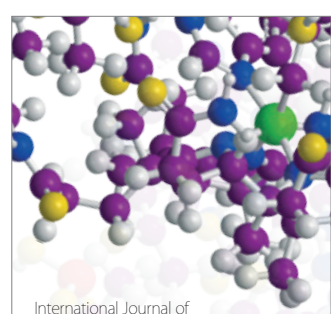

Carbohydrate Chemistry

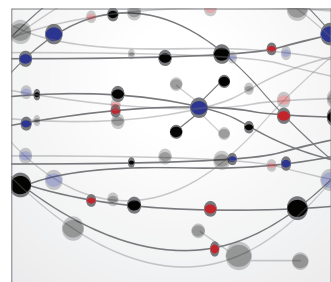

The Scientific World Journal
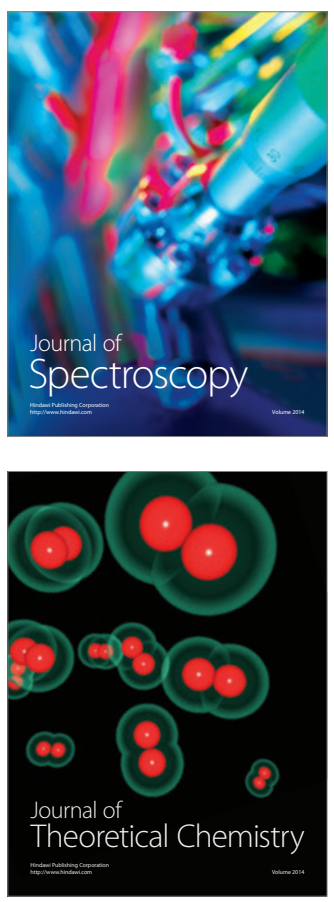
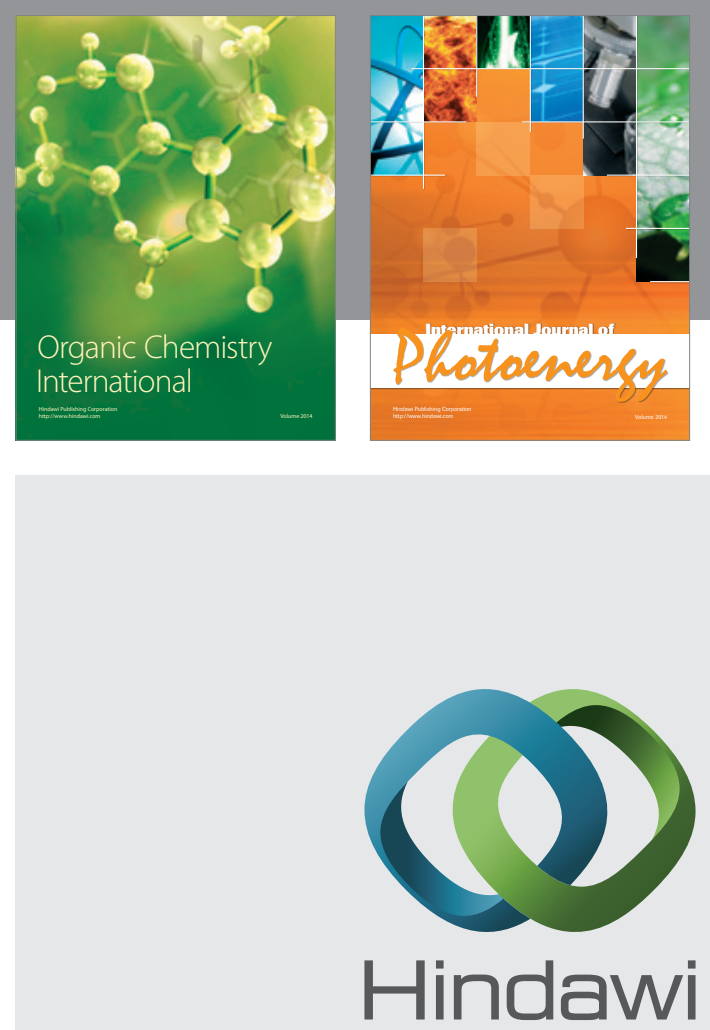

Submit your manuscripts at

http://www.hindawi.com
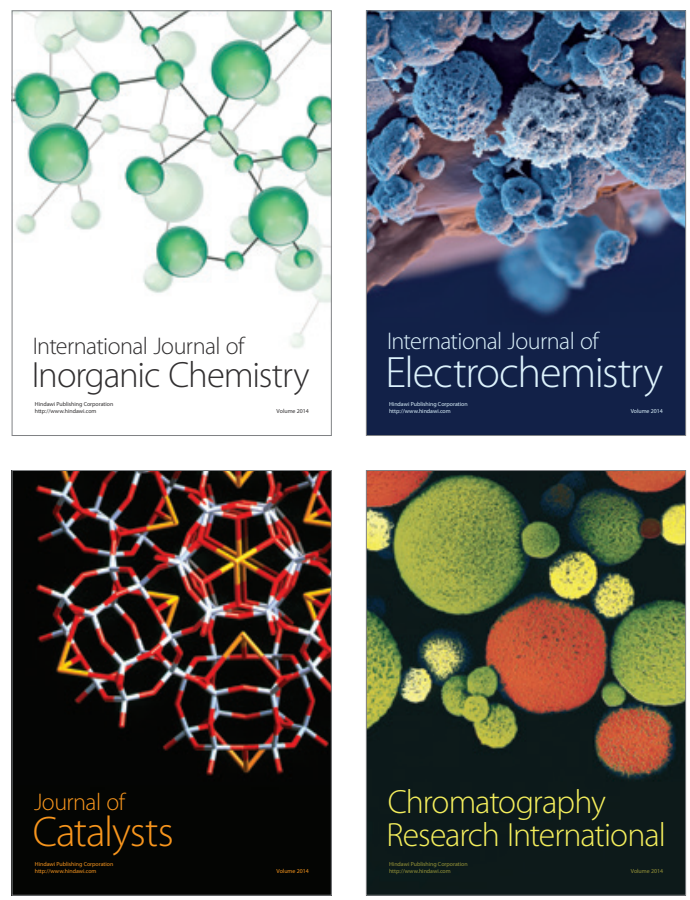
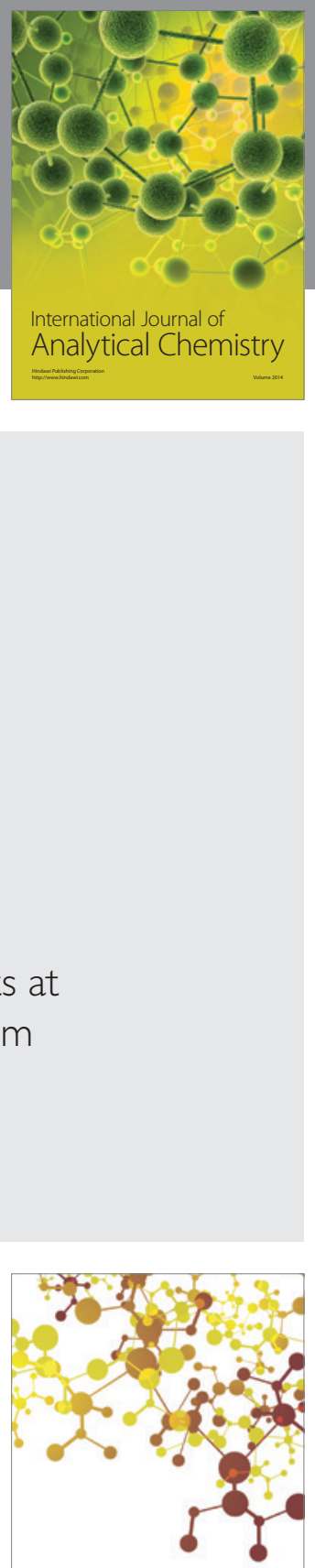

Journal of

Applied Chemistry
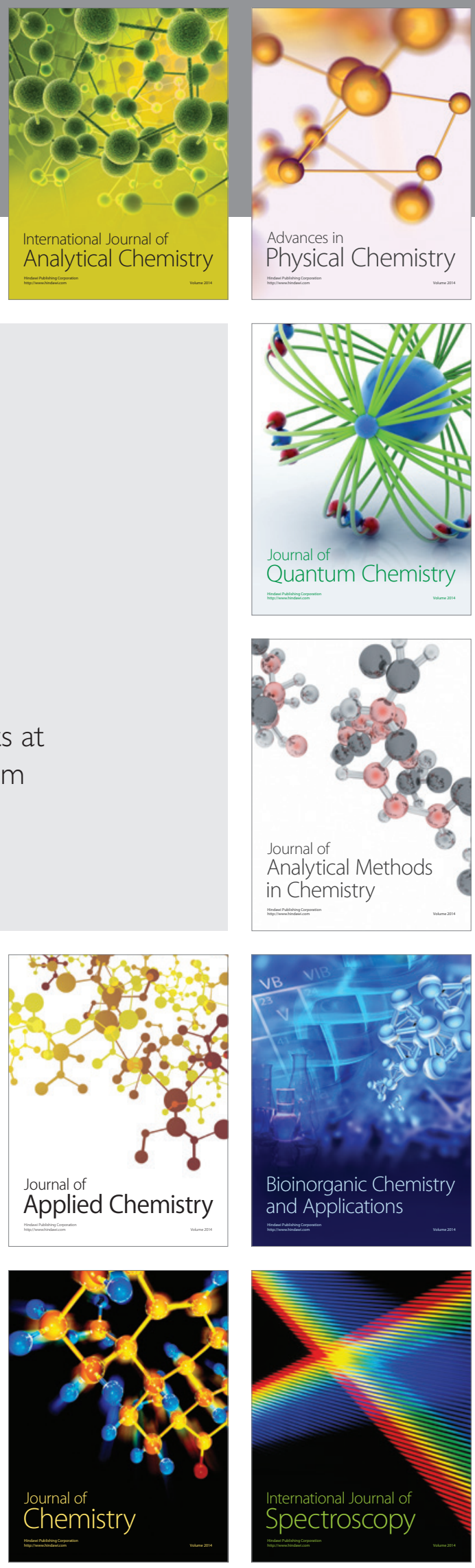